\title{
CONTENTS OF SOME MACROBIOGEN ELEMENTS IN SOIL AND THEIR UPTAKE AT ALFALFA
}

\author{
Elmi Jusufi $^{1}$, Mentor Zekiri ${ }^{2}$, Natasha Gjorgovska ${ }^{1}$, Vesna Levkov ${ }^{1}$ \\ ${ }^{1}$ University Ss. Ciril and Methodius in Skopje, Institute of Animal Science, \\ Bvd. Ilinden 92a, 1000 Skopje, Republic of Macedonia \\ ${ }^{2}$ Ministry of Agriculture, Forestry and Water Economy, Republic of Macedonia, \\ Blvd. Ilinden, 1000 Skopje \\ eljmi_jusufi@hotmail.com
}

\begin{abstract}
In this research, the test parcels from for different locations, where the alfalfa variety Banat ZMS II is cultivated, were included. The aim of this abstract is to establish the content of macrobiogen elements $(N, P, K)$ in the soil, i.e. fertility of test soils and their attendance in the dry mass of the cultivated alfalfa. The results from the agrochemical analysis of soils from the test parcels in v. Saraj (Skopje), v. Raduša (Skopje), v. Jegunovce (Tetovo) and v. Kodžilari (Veles) have indicated different quantities of the same examined macrobiogen elements, i.e. their different fertility. The examined macrobiogen elements $(\mathrm{N}, \mathrm{P}, \mathrm{K})$ in the dry plant mass of the sown alfalfa on aforementioned location, have showed their different value in dependence of the degradation of soil, with all the same, whereby and from their amount proportion in the soil solution. The contents of N, P and K in the dry mass of alfalfa leaves and stems, is also significantly different, which points at their diverse dynamics on uptake and accumulating from distinct parts of alfalfa as forage culture.
\end{abstract}

Key words: macrobiogen elements (N, P and K); soil; alfalfa; dry mass; dynamic; uptake; accumulating

\section{СОДРЖИНА НА НЕКОИ МАКРОБИОГЕНИ ЕЛЕМЕНТИ ВО ПОЧВАТА И НИВНОТО УСВОЈУВАҢЕ КАЈ ЛУЦЕРКА}

\begin{abstract}
Со истражувањата се опфатени опитни парцели од четири различини локалитети на кои е одгледувана луцерка од сортата Банат ЗМС II. Целта на овој труд е да се утврдат содржината на макробиогените елементи $(\mathrm{N}, \mathrm{P}, \mathrm{K})$ во почвата, односно плодноста на опитните почви, и застапеноста на овие елементи во сувата маса на одгледуваната луцерка. Добиените резултати од агрохемиската анализа на почвите од опитните парцели во c. Сарај (Скопје), с. Радуша (Скопје), с. Јегуновце (Тетово) и с. Коџилари (Велес) покажаа различна снабденост на почвите со испитуваните макробиогени елементи, т.е нивна различна плодност. Испитаните макробиогени елементи (N, P, K) во сувата растителна маса на засеаната луцерка од наведените локалитети покажаа различна вредност во зависност од степенот на снабденоста на почвата со нив, како и од нивниот количински сооднос во почвениот раствор. Исто така, содржината на N, Р и K во сувата маса на луцеркините лисја и стебленца значително се разликува, што укажува на различна динамика на усвојување и акумулирање во одделните делови на луцерката како фуражна култура.
\end{abstract}

Клучни зборови: макробиогени елементи (N, P, K,); почва; луцерка: сува маса; динамика; усвојување; акумулирање

\section{INTRODUCTION}

Alfalfa is the most used culture as stock food. The nutrition value of the alfalfa is bigger comparing with the other cultures of hay (Lukić et al.,
1994). It has high potential for production and a middle energetic value. The nutrition value, as a stock food, is very high due to the high value of proteins (in leaf $28.81 \%$, in stem $10.7 \%$ and in hay 20.67\%) (Gagačev and Jekić M. 1989). 
Insufficient quantities of minerals, in the daily intake animal diet, can result in animal health, and problems in their growth and development and even in their death (Gueguen et al., 1989).

The alfalfa is reacting very well on the introduction of nitrogen mineral fertilizers, and that is resulting with in increasing the green content per square meter and percentage of dry metter (Popović et al., 1972; Kozarova, 1985).

\section{METHODS AND MATERIALS}

The analysis of the agrochemical characteristics of the soil has been made on a zik-zak based method of taking samples on certain soil depth and after that preparing of the representative sample for chemical analysis from the investigated area.

Nitrogen content has been analyzed by the modificated method of Tjurin and Kononova by D. Stojkovska, where phosphor has been analyzed spectrophotometrically (A-L method) and for determination of potassium, the flame-photometric technique has been used.

The samples for determination of dry matter of alfalfa growth in the field conditions are taken in the flowering stage. For the quality determination, samples from whole plants have been taken, leaf and stem, they have been ground after analyzing the fresh and air dry matter.

The content of the total nitrogen has been determined by the Kjeldah (macro) method, on the phosphorous $\left(\mathrm{P}_{2} \mathrm{O}_{5}\right)$ spectrophotometric (Gericke and Kurmies, 1952) and potassium $\left(\mathrm{K}_{2} \mathrm{O}\right)$ flamephotometric according to Sarić et al. 1990.

\section{RESULTS AND DISCUSSION}

\section{Agrochemical analysis of soils}

The results of the agrochemical analysis of the soil on the testing fields of alfalfa, for nitrogen, phosphorous and potassium are given in Table 1.

Available nitrogen $(\mathbf{N})$. The determinate contents of available forms of nitrogen (Table 1) point out that there is sufficient content of nitrogen in the soil from the four testing areas (good fertility).

Phosphorus $\left(\mathbf{P}_{2} \mathbf{O}_{5}\right)$. From the content values of available phosphorus $\left(\mathrm{P}_{2} \mathrm{O}_{5}\right)$ in soil (Table 1), the testing area Kodžilari shows a large content (50.75 mg/100 g phosphorus) and Saraj (36.02 $\mathrm{mg} / 100 \mathrm{~g}$ ) too. Raduša shows less content of phosphorus $(28.90 \mathrm{mg} / 100 \mathrm{~g})$ and the lowest content is in Jegunovce $(23.17 \mathrm{mg} / 100 \mathrm{~g})$. According to this, the soils in Kodžilari and Saraj are fertile, and in Raduša and Jegunovce are low fertile.

Table 1

Agrochemical properties of the soil

\begin{tabular}{lccccccc}
\hline \hline \multirow{2}{*}{ Location } & \multicolumn{5}{c}{ Available $(\mathrm{mg} / 100 \mathrm{~g})$ in soil /useful in the soil/ } \\
\cline { 2 - 7 } & $\mathrm{NO}_{3}-\mathrm{N}+\mathrm{NH}_{4}-\mathrm{N}$ & \multicolumn{2}{c}{$\mathrm{P}_{2} \mathrm{O}_{5}$} & \multicolumn{2}{c}{$\mathrm{K}_{2} \mathrm{O}$} \\
\hline v. Saraj & 7.52 & 100.0 & 36.02 & 100 & 3.3 & 100.0 \\
v. Jegunovce & 7.62 & 97.1 & 23.17 & 64.4 & 4.9 & 148.5 \\
v. Raduša & 9.75 & 129.6 & 28.90 & 80.3 & 9.9 & 300.0 \\
v. Kodžilari & 9.38 & 124.7 & 50.75 & 140.8 & 68.2 & 2066.6 \\
\hline \hline
\end{tabular}

Potassium $\left(\mathbf{K}_{2} \mathbf{O}\right)$. Determination of the available quantities of potassium in testing areas shows good content in Kodžilari $(68.20 \mathrm{mg}$ ), and low content (less than $10 \mathrm{mg} / 100 \mathrm{~g}$ soil) in Raduša $(9.89 \mathrm{mg} / 100 \mathrm{~g})$, Jegunovce $(4.87 \mathrm{mg} / 100 \mathrm{~g})$ and Saraj (3.33 mg/100 g).

\section{The content of total nitrogen}

The content of total nitrogen. The content of total nitrogen in alfalfa is in the optimal limits and is between $3.5-5.5 \%$ in dry matter (Neubert, 1970).

Bigger amount of total nitrogen (Table 2) has been determined in dry matter in alfalfa leaves in the testing area of Saraj (4.93\%) and Kodžilari (4.82\%), while lower content in Raduša (4.44\%). In the dry matter in alfalfa stems the content of total nitrogen is significantly lower than in leaves, with the same content ratio as in leaves, the largest content is in stems in Saraj (2.10\%) and Kodžilari $(2.06 \%)$, while in Jegunovce (1.79 \%) and Raduša $(1.72 \%)$ it is lower.

The difference between the nitrogen content in alfalfa dry matter on the testing fields points out the correlation between acceptation of mineral nitrogen, not only from the availability in the soil, but from the present quantities of phosphorus and potassium that show positive influence. This is most obvious in the Saraj testing region (area), where the additional use of the mineral fertilizer (NPK) results in significant enlarging of nitrogen in dry matter. 
Table 2

Content of total nitrogen

\begin{tabular}{|c|c|c|c|c|}
\hline \multirow{3}{*}{ Location } & \multicolumn{4}{|c|}{$\%$ in dry matter } \\
\hline & \multicolumn{4}{|c|}{ Flowering } \\
\hline & \multicolumn{2}{|c|}{$\begin{array}{l}\text { Total nitrogen } \\
\text { (N) }\end{array}$} & $\begin{array}{c}\text { Phosphorus } \\
\left(\mathrm{P}_{2} \mathrm{O}_{5}\right)\end{array}$ & $\begin{array}{c}\text { Potashium } \\
\left(\mathrm{K}_{2} \mathrm{O}\right)\end{array}$ \\
\hline & \multicolumn{4}{|c|}{ Leaves } \\
\hline v. Saraj & $4.93 \pm 0.004$ & 100.0 & $0.92 \pm 0.05 \quad 100.0$ & $1.80 \pm 0.10 \quad 100.0$ \\
\hline v. Jegunovce & $4.68 \pm 0.21$ & 94.9 & $0.77 \pm 0.13 \quad 83.7$ & $2.10 \pm 0.10 \quad 116.7$ \\
\hline v. Raduša & $4.44 \pm 0.22$ & 90.1 & $0.69 \pm 0.06 \quad 75.0$ & $2.04 \pm 0.16 \quad 113.3$ \\
\hline \multirow[t]{2}{*}{ v. Kodžilari } & $4.82 \pm 0.19$ & 97.8 & $0.81 \pm 0.06 \quad 88.0$ & $3.44 \pm 0.13191 .1$ \\
\hline & \multicolumn{4}{|c|}{ Steams } \\
\hline v. Saraj & $2.10 \pm 0.01$ & 100.0 & $0.71 \pm 0.05 \quad 100$ & $2.00 \pm 0.07 \quad 100.0$ \\
\hline v. Jegunovce & $1.79 \pm 0.02$ & 85.2 & $0.45 \pm 0.10 \quad 63.4$ & $2.46 \pm 0.17 \quad 123.0$ \\
\hline v. Raduša & $1.72 \pm 0.14$ & 81.9 & $0.36 \pm 0.04 \quad 50.7$ & $2.36 \pm 0.23 \quad 118.0$ \\
\hline v. Kodžilari & $2.06 \pm 0.03$ & 98.1 & $0.59 \pm 0.05 \quad 83.1$ & $4.49 \pm 0.21224 .0$ \\
\hline
\end{tabular}

The correlation of adopted nitrogen with the content of nitrogen in soil and other macrobiogenic elements is established by the investigation of Jerimić (1981), Gagačev (1989) and also by Karczmarczyk et al. (2003) conducted in other forage cultures.

The content of phosphorus $\left(\mathrm{P}_{2} \mathrm{O}_{5}\right)$. For optimal growth and development of alfalfa the optimal quantities of phosphorus are between $0.3-$ $0.5 \%\left(0.68-1.14 \mathrm{P}_{2} \mathrm{O}_{5}\right)$, and the limits are 0.20 $0.35 \%$ low value quantities of phosphorus, and between $0.71-1.00 \%$ of the dry matter are high value quantities of phosphorus.

The determinate content of phosphorus (Table 2) in the dry matter in stems vice versa leaves are significantly lower, Saraj $22.83 \%(0.71 \%)$ and Kodžilari $27.17 \%(0.59 \%)$, respectively in Raduša the difference is more obvious, it's lower $48.83 \%(0.36 \%)$. The bigger content of phosphorus in the dry plant matter in Saraj and Kodžilari is in accordance with the better content of available phosphorus in the soil, which is $36.02 \mathrm{mg} / 100 \mathrm{~g}$, and in Kodžilari it is $50.75 \mathrm{mg} / 100 \mathrm{~g}$ soil.

Significant lower contents of phosphorus are measured in the dry matter of alfalfa leaves and stems in Raduša, as a result of lower content of phosphorus in soil $(28.90 \mathrm{mg} / 100 \mathrm{~g}$ soil), while the lower content differences in Jegunovce are correlated with higher content of active calcium in soil $(730.0 \mathrm{mg} / 100 \mathrm{~g}$ soil) which is adoption inhibitor (Jusufi, 2009). The results are in accordance with investigations conducted by Neubert and Bergman (1976), K"drev and Stojanova (1985), Parmasivam and Richardson (2002).

The content of potassium $\left(\mathrm{K}_{2} \mathrm{O}\right)$. The optimal quantities of potassium $\left(\mathrm{K}_{2} \mathrm{O}\right)$ in alfalfa in the dry matter are $2.1-3.5 \%$ (Neubert, 1970).

The established quantities of potassium $\left(\mathrm{K}_{2} \mathrm{O}\right)$ in air dry matter alfalfa (Table 2$)$ is $2.0 \%$ in Saraj to $4.49 \%$ in Kodžilari and comparing with the leaves $1.80 \%$ in Saraj to $3.44 \%$ in Kodžilari, are on average higher for $18.62 \%$. Significant lower content of potassium is found in alfalfa in Saraj $(1.9 \%)$, respectively higher in Kodžilari $(3.96 \%)$ which is in correlation with better content of potassium in the soil in Kodžilari (68.20 $\mathrm{mg} / 100 \mathrm{~g}$ soil), respectively lower in Saraj (3.33 $\mathrm{mg} / 100 \mathrm{~g}$ soil). The better content of potassium in alfalfa in the testing area of Raduša, Jegunovce and Saraj (Table 1) is the result of the significant higher quantities of available potassium in the soil (Karczmarczyk et al., 2003)

\section{CONCLUSION}

- The soils from the testing area are well provided with available nitrogen (good fertility), respectively with available phosphorus in the Kodžilari and Saraj soils (which are with poor fertility), poor fertility of the soils in Jegunovce and Raduša, while sufficient content of potassium is only in Kodžilari.

- The meassured content of total nitrogen in the dry plant matter results in optimal content, and the average ratio of total nitrogen in leaves and stems is $2.45: 1.0$.

- The positive influence of the intensity of adoption of the total nitrogen was as a result of the existing quantities of available phosphorus and potassium in soil (Kodžilari).

- Dry plant matter is with optimal quantities of phosphorous which is significantly higher in leaves vice versa stems. At the same time, the degree of adopted phosphorus is related from the level of their quantities in soil (Raduša and Kodžilari).

- The measured potassium in the dry matter is in the frame of optimal limits, but the average content in leaves is lower for $17.23 \%$ respectively in stems. The adopted quantities of potassium result with in positive correlation with the level of 
the existing potassium in the soil solution (Kodžilari and Saraj).

- The knowledge gained during the examination is input for the future examination of this kind, and the results are not important just for alfalfa as a forage culture, but also for other cultures which are in the scope of interest as animal food and for the humans as well.

\section{REFERENCES}

[1] Gagačev, V., Jekić, M. (1989): Uticaj NPK đubriva i saturacionog mulja na prinos i hemijski sastav lista, stabljike i sena lucerke. Zemljište i biljka, 38, 2, 137-148, Beograd.

[2] Gericke, S. und Kurmies, B. (1952): Kolometrische Bestimmung der Phosphorsaure mit Vanadat-molybdat. Zeitschr. Anal. Chem. 137, 15-22.

[3] Gueguen, L., F. Meschy, Durand, M. (1989): Recent progress in the assesment of phosphorus and calcium requirements of ruminants. International Meeting on Mineral nutrition and Mineral Requirements in Ruminants. Kyoto, Japan, 123-126.

[4] Jeremić, D., Stošić, M. (1981): Proučavanje uticaja različitih nivoa azota $\mathrm{u}$ ishrani vrsta iz familije Fabaceae i Poaceae i njihovih smeša. Agrohemija, No. 11-12, Beograd.

[5] Јусуфи, Е. (2009): Влијаниейо на хемискииее својсиива

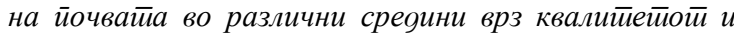

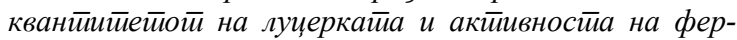

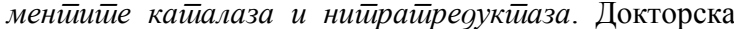
дисертација, ПМФ, Скопје.

[6] Karczmarczyk Stanislav, Cezary P., Koszanski, Z. (2003): Effect of supplemental irrigation and mineral fertilization on physiological processes in plants and biological value of crops cultivated on sandy soil in North-Western Poland. Agricultural Engineering, 5-6, 100-102, Plovdiv.

[7] Къдрев, Т., Стоянова 3. (1985): Метаболизъм на азота в царевични растения при различни концентрации цинк в хранителния раствор, Физиология на растенията, Том. 7, 136-139, София.

[8] Козарова Мариа (1985): Динамика на чистата продуктивност на фотосинтезата при различни нивоа на азотно хранене при люцерната. Физиология на растенията. Т. 7, с. 140-143, София.

[9] Lukić, D., Katić, S. (2000): Produktivnost nekih domaćih i stranih sorti lucerke. Selekcija i semenarstvo, 1, 77-80, Novi Sad.

[10] Neubert, P., Warzidlo, W., Vielemeyer, H. P., Hundt, I., Gollmick, E., Bergmann, W. (1970): Tabellen zur Pflanzenanalyse. Erste orientierende Übersicht. Inst. für Pflanzenernahrung der Akademie der Landwirtschaftswiss. der DDR, Jena.

[11] Paramasivam, S., J. P. Richardson (2002): Phosphorus alleviation of cadmium phytotoxicity. Journal of Plant Nutrition, Volume 25, Issue 9, 2027-2034.

[12] Popović Ž., Tomić R. Ranković M. (1972): Prilog proučavanju uticaja mineralnih đubriva i navodnjavanja na produktivnost lucerke (Medicago sativa L.): Zavod za krmno bilje, Kruševac. God. XXV, sv. 91, 138-147

[13] Sarić, M., Kastori R., Petrović, M., Stanković, Ž., Petrović, N. (1990): Praktikum iz fiziologije biljaka, II izdanje, Naučna knjiga, Beograd. 